\title{
Ideology Versus Multilingualism in South Africa: Should National Legislation Be Published in All Official Languages?
}

\author{
Cornelus Johannes Alexander Lourens
}

Faculty of Law, University of North-West, South Africa

Copyright $(2017$ by authors, all rights reserved. Authors agree that this article remains permanently open access under the terms of the Creative Commons Attribution License 4.0 International License

\begin{abstract}
Does the failure to publish all national legislation in all official languages constitute unfair (unlawful) discrimination? The question whether 'officiality' implies the obligation that all national legislation should be published in all official languages is discussed with references to the historic development of the Constitutional Language provisions in South Africa, international and foreign law are referred to as well as the three Lourens decisions. The restrictive approach by the court is criticised as they sanctioned an unfair language discriminatory practice, that English is elevated to the only true official language. The need for the intellectualisation/modernising of the indigenous languages is highlighted. In the conclusion the challenge of a constitution pretending to be the supreme law of the Country against a National Government, without any political will to enhance the indigenous languages without which speakers' have de facto accepted English as super official language is evaluated.
\end{abstract}

Keywords Official Language, Unfair Language Discrimination, Intellectualization/Modernising, Hegemony, Language Diversity

\section{Introduction}

South Africa as a multilinguistic and multicultural country has as its motto in the coat of arms expressed in the San language of the extinct /Xam people: '!ke e:/xarra//ke' and it means 'diverse people unite', or 'people who are different joining together'. This can rightly be stated to be the lodestar of the Constitutional settlement of 1993. ${ }^{1}$ [1]

How did it come about, you may ask, that the leaders of South Africa preferred a multilingual language dispensation rather than an 'obvious' monolingual choice of English

[1] The Constitutional Assembly adopted the final Constitution in 1996, which was thereafter certified by the Constitutional Court. only?

The challenge with the negotiations to create a democratic South Africa in regard to the National language question was to reconcile the Afrikaner minority Government's initial demand that the status of Afrikaans as official language may not be diluted on the one hand, and the majority African movement, the ANC's, which took the view ${ }^{2}$ to choose English as the only official language. The compromise [2] was reached to include all 9 African languages in s6(1) of the Constitution together with Afrikaans and English as official languages.

The answer to the poignant question in regard to the question how human worth was affirmed by the Constitution in regard to the indigenous African languages, ${ }^{3}$ was thus so given. Multilingualism was also chosen as an anti-racism tool to promote reconciliation.

The first president of the integrated South Africa, President Nelson Mandela, contextualised the new language dispensation:

'[W] e are extremely, proud that the new Constitution asserts equality among South Africa's languages, and that, for the first time, the languages particularly of the Khoi, Nama and San communities will receive the attention they deserve, after years of being trampled upon in the most humiliating and degrading manner.' [3]

This paper focuses on the question whether the 'official status' granted to the eleven official languages, within the context of South Africa being a so-called Constitutional state in which the Constitution is the supreme law of the land and of which the principle of the Rule of Law are core principles of the Constitution, necessitates that all National Legislation should be published in all the official languages.

The question whether the Parliament or the executive authority by failing to translate and publish all National

[2] Of the rest of the African decolonized country's approach to choose for the colonial language.

[3] See 10.1 infra. 
Legislation into all eleven official languages commits a practice of unfair language discrimination will be discussed. ${ }^{4}$ As the granting of official status to the eleven official languages is enshrined in the founding part of the Constitution, any relativisation thereof should be looked on with circumspection, is argued. ${ }^{5}$

In order to come to a conclusion, a short historic background is given, thereafter Parliament's and the executive authorities' interpretation of its obligations will be reviewed in the light of international and foreign law and the current interpretation by the South African courts, where after I will give my perspective on the answer to the current ideological approach.

\section{A Few Historic Footsteps towards the Current Language Clause}

The Anglicization of South Africa to the detriment of the other languages came a long way and I quote from the Oxford History of South Africa: [4]

'That the British authorities saw the importance of language is apparent from the steps periodically taken to compel the public use of English. They applied pressure first in the schools; they extended it by proclamation to the courts from the late 1820s onwards; in 1853 they made English the exclusive language of Parliament; and by [1870] they appeared to be triumphing on all fronts. By the middle 1870's the Chief Justice, J.H. de Villiers, could tell an audience that although the time is still far distant when the inhabitants of this colony will speak and acknowledge one common mother-tongue, it would come at last, and when it does come, the language of Great Britain will also be the language of South Africa.' p. 73-74

I must pause here, and it is my perception, that the current Government is busy attempting to actualise the vision of judge JH de Villiers.

At the National Convention of 1909, which led to the union of South Africa after the horrific second Anglo Boer $\mathrm{War}^{6}$ and the suppression of Dutch Afrikaans immediately thereafter, the South Africa Act, 1909 was adopted. Section 137 thereof provided in regard to official languages that:

'both the English and Dutch languages shall be official languages of the Union, and shall be treated on a footing of equality, and possess and enjoy equal freedom, rights and privileges; all records, journals, and proceedings of Parliament shall be kept in both languages, and all Bills, Acts and notices of general public importance or interest issued by the Government

[4] The SA Constitution uses 'unfair discrimination' instead of the International term 'unlawful discrimination' but it is similar.

[5] S6 of the Constitution may be amended with a supporting vote of two thirds of the National Assembly and the support of 6 Provinces in the National Council of Provinces. (See S74(3).)

[6] 11 October 1899 until 31 May 1902. of the Union shall be in both languages. ${ }^{, 7}[5]$

The same dispensation was maintained when South Africa became a Republic in 1961 [6] and in 1983, when the new 'Tricameral' Constitution was introduced. [7]

A people's congress was held on 25 and 26 June 1955 at Kliptown, Johannesburg which created the renowned 'Freedom Charter' which became the Bible for the liberation struggle against apartheid. It included the following regarding language: All people shall have equal rights to use their own languages.

The African languages had official status in the so-called home lands. [8] Within the official structures of the 'Bantustan' policy of the apartheid regime. ${ }^{8}$

The Soweto Uprising of the learners on 16 June 1976 was a turning point in South Africa and for the language dispensation. The renowned $\operatorname{Dr}$ Neville Alexander contextualized it the best when he said that it became obvious very quickly that Afrikaans was just a trigger for the uprising and that the real issue was the whole apartheid system. [2] He contextualised it as follows:

'...the consequences of the Soweto Uprising are still with us today. It's basically the Bantu Education system, and the way in which mother tongue-based education was compromised through Bantu Education, but also the loss of lives around the struggle against Afrikaans. That's something that people don't forget. It's a bit like the Afrikaner nationalist attitude was against English, from the Anglo Boer War, and the fact that thousands of Afrikaner women and children were killed in the British concentration camps. And part of that struggle was seen as a struggle for Afrikaans and against English. Although it's changing, it's changing very slowly. Every now and again people come back to the fact that Afrikaans is a language of the oppressor. ${ }^{9}$...In one sense of course, the Soweto Uprising rang in, heralded the overthrow of apartheid. The whole wave after wave of revolutionary action that eventually led to a negotiated settlement. In another sense - from a language point of view - it really entranced the position against Afrikaans, but also for English as opposed to African languages. From the leadership even from the more adult leadership, there was a sense of coming out for African Languages. It was support for English as opposed to Afrikaans. In other words, the black people

[7] South African Act 1909, as amended by the Official Languages of the Union Act, Act 8 of 1925 in terms of which Afrikaans was added as a variant of Dutch.

[8] South Africa was divided through the policy of apartheid (separateness) in a white land with separate group areas for whites, coloureds, Indian and black people in the 'white lands' and 10 bantustans established according to ethnicity.

[9] 'So in fact it's very interesting that people who say that do not realise that they are quoting an Anglo-Boer War leader, an Afrikaner, a Boer Leader, the president of the Free State of that time, Marthinus Steyn. He was the one, and he was quoting somebody from Flanders in the struggle of the Flemish people. He was quoting that person when he said that the language of the oppressor in the mouth of the slave is a language of oppression. And he was talking about English. So to call Afrikaans the language of the oppressor is basically to quote Steyn. And most people are not even aware of the paradox.' p. 102 [2] 
were still fighting the Anglo-Boer War. And that is of course a tragedy, which we now revisit and address in a different way. Fortunately, I think we are getting out of it, but it is very, very slow...' p. 152 [2]

The Constitution of 1996 declared that South Africa has eleven official languages. Dr Neville Alexander stated the reason for the granting of official status to the nine African languages being the fact that they had partial regional official status in the home lands before. [2]

\section{The Legal Context of Section 6: The Language Clause}

The precursor of the Constitution of 1996 was the negotiated Interim Constitution of $1993^{10}$ which had an elaborate protection of established language rights. [9] The final Constitution passed in $1996^{11}$ [10] had to be certified by the Constitutional Court which was done with the criteria set in the Constitutional Principles in the 1993 Constitution. ${ }^{12}$ [9]

The said principle in regard to languages reads as follows: 'the diversity of language and culture shall be acknowledged and protected, and conditions for their promotion shall be encouraged' [9].

On a challenge that section 6 of the Constitution does not comply with the said principle XI and section 3 of the Interim Constitution, the Constitutional Court found that: [11]

\begin{abstract}
'The granting of official status to languages is a matter within the sole responsibility of the $C A$ (Constitutional Assembly), and it is the CA's (Constitutional Assembly's) considered determination in that regard that is reflected in NT (new text) 6(1). The balance of NT (new text) 6 is directed at fostering linguistic diversity...' (par 210) and

'... It appears to be the contention that the status of Afrikaans is diluted under the NT (new text), relative to the IC (Interim Constitution). But NT (new text) 6, like the rest of that document, must be tested against the $C P$ (Constitutional Principles), and not against the IC (Interim Constitution). In any event, the NT (new text) does not reduce the status of Afrikaans relative to the IC (Interim Constitution): Afrikaans is accorded official status in terms of NT (new text) 6(1). Affording other languages, the same status does not diminish that of Afrikaans. ' par 212
\end{abstract}

The Constitutional Court thus in my view clearly distinguishes between section $6(1)$, the recording that the

[10] The historic compromise of 1993 between the white minority government and the African majority culminated in the Interim Constitution of 1993

which provided for a Constitutional Assembly which had to prepare a Final Constitution founded on agreed principles.

[11 ] Act 108 of 1996 herein referred to as the Constitution.

[12] Constitutional Principle XI of the INTERIM Constitution 1993. eleven languages had official status, and the balance of the sub-clauses which promotes diversity. A purposive and intentional decision by the Constitutional Assembly, which was tasked to finalise the Constitution of 1996, had made the firm choice of the eleven official languages which was thus certified.

Section 6 can be typified as the embryonic language clause with the obvious understanding that officiality in a constitutional state, means indeed 'official'. In the light of the fact that the specific meaning for every word in the Constitution should be given and as South Africa is a constitutional state with the enshrined principle of constitutionalism, the granting of officiality to the nine African languages restored the infringement of human worth (dignity) of the said languages' speakers. It should thus be recognised as a purposive action of levelling the statuses of the eleven languages. The Constitution embodies a normative value system which is imbedded in human dignity and equality. The reasonable citizen will thus have a legitimate expectation that the choice of the specific official languages would by necessary implication entail certain fruits of which I contend, the publication of all National Legislation in the official languages, is one of the most important consequences of the official status granted to them. The fleshing out of this through the court is thus a normal process in a constitutional state.

I turn now to the vexed question, what is the Parliaments' and the executives' approach to the translation obligation in regard to legislation of National nature?

\section{International and Foreign Law Perspective on Officiality}

In terms of section 39 (1)(b) of the Constitution, the court must, in interpreting, consider international law and in terms of section 39 (1)(c) may consider foreign law. Section 233 of the Constitution provides that when interpreting any legislation, every court must prefer any reasonable interpretation of the legislation that is consistent with international law over any alternative interpretation that is inconsistent with international law.

In this regard, the finding by the Human Rights Committee of the United Nations in J.G.A Diergaardt v Namibia [12] that the authors, as Afrikaans speakers, are victims of a violation of article 26 of the Covenant on Civil and Political Rights and the Optional Protocol thereto, is significant. Namibia's official language is English only and in an official circular, officials of the Namibian government were issued to the effect that officials of the government of Namibia, notwithstanding the fact that they could speak Afrikaans, were forbidden to use Afrikaans with the complainants. It is relevant to mention commissioner Nisuke Ando's finding that the choice by a State of an official language as follows is a state's prerogative. He remarks [12]:

'...but considering that each sovereign State may 
choose its own official language and that the official language may be treated differently from non-official languages..., ${ }^{13}$ p. $10-11$

Dr Fernand de Varennes [13] simplified the position as follows:

'...Put simply, one can infer overall that a difference of treatment between an official language and a non-official language in their use by authorities will be generally more "acceptable" than differences of treatment between official languages, though in both cases the prohibition of non-discrimination still demands that any language preference by authorities still satisfy the test of a reasonable or justified distinction.' p. 35

In the judgment of the European Court of Human Rights, Mentzen alias Mencina v Latvia, ${ }^{14}$ [14-16] the issue of the prerogative of a State in determining which languages are official and what the consequences thereof entail, was dealt with and I quote:

'Consequently, by making a language its official language, the State undertakes in principle to guarantee its citizens the right to use that language both to impart and to receive information, without hindrance not only in their private lives, but also in their dealings with the public authorities. In the Court's view it is first and foremost from this perspective that measures intended to protect a given language must be considered. In other words, implicit in the notion of an official language is the existence of certain subjective rights for the speakers of that language.' p. 27 [13]

The African Commission for Human and People's Rights gave also the expected weight to officiality in the case: Kevin Mgwanga Gunme et al v Cameroon [17] in terms of the African Charter ${ }^{15}$.

'English is one of the official languages in Cameroon. Southern Cameroonians had a legitimate expectation that the English language could be used to conduct official business, including the registration of companies. The Commission makes a finding that the refusal to register companies established by Southern Cameroonians on account of language amounted to a violation of Article 2 [non-discrimination] of the African Charter. Imposing the exclusive use of only one official language where this unreasonably excludes the use or disadvantages individuals in their use of another official language was in this particular case, a situation of discrimination under African human rights standards.' p. 31-35 [13]

'If the restriction or even exclusion as to the use of a

[13] He gave a dissenting minority judgement on page 10-11 but underscored the principle of choice of an official language by a State.

[14] See also section 4 of the Constitution of Latvia [15] read together with section 19 of the Latvian Official Languages Act [16].

[15] This charter is part of the South African law as it was ratified by the South African parliament. particular official language is unjustified or unreasonable, then the difference of treatment which impacts negatively on individuals denied the use of their official language will constitute a prohibited form of discrimination ....' p. 31-35 [13]

Dr Fernand de Varennes [18] referred to the case [19] of the province of Manitoba in Canada, where the initial constitutional provision (under the Manitoba Act, 1870) indicated that the: 'Acts of the Legislature shall be printed and published in both those languages.'

The constitutional interpretation of this provision is that all of its Provincial Laws must be in both, and failure to do so leads to the unconstitutionality, and therefore invalidity, of all legislation in English only. For a variety of reasons, only English was used in the laws of Manitoba between 1890 and 1980 - almost 100 years of legislation. Ultimately, the Supreme Court of Canada ruled in the Reference re: Manitoba Language Rights of 1985 that all laws during this long period which had not been published in both of the provinces official languages were indeed unconstitutional, invalid, and of no force and effect. However, as this would undermine the rule of law in the province since it would leave that part of law effectively 'lawless' with its entire legal system in limbo, it sought to find a remedy that would enforce constitutional supremacy while simultaneously protecting the rule of law. The final outcome was that the Supreme Court declared that Manitoba's invalid laws would have temporary force and effect for a period of time during which the province was to translate, re-enact and publish almost 100 years and 4, 000 pieces of legislation bilingually, a task accomplished in about five years.

The prescriptions of National States in regard to the use of official languages for the publication of legislation are generally not specific as it is in my view implied by making a language an official language. [20]

Where more than one language is made official, it highlights this subject matter. ${ }^{16}[21]$

Singapore has 4 official languages and the language clause in its Constitution in this regard states: [22]

'Article 153A (1) Malay, Mandarin, Tamil and English shall be the 4 official languages in Singapore. (2) The national language shall be the Malay language and shall be in the Roman script: Provided that - (a) no person shall be prohibited or prevented from using or from teaching or learning any other language; and (b) nothing in this Article shall prejudice the right of the Government to preserve and sustain the use and study of the language of any other community in Singapore.'

Section 142 of the Constitution of the Democratic Republic of Congo has an interesting, but relevant requirement of publication which reads as follows: [23]

'The statute enters into force thirty days after its

[16] Switzerland, Canada and Belgium are examples of Countries with developed legal prescriptions regarding publication of legislation. 
publication in the Official Journal unless it provides otherwise. In all cases the Government ensures the dissemination in French and in each of the four national languages [of the statute] within a period of sixty days following the promulgation thereof.'

In conclusion, it is my view that officiality implies by necessary implication that the State, either the Parliament or Executive Authority, should make all National Legislation in all official languages available on the aforesaid international and foreign law principles.

\section{Parliament's Approach towards the Publication of Legislation in Official Languages}

The speaker of the National Assembly's and the Chairperson of the National Council of provinces' view is that there is no constitutional prescription that obliges Parliament to translate and publish the National Legislation in all eleven official languages. It is based on its contention on section $81^{17}$ and $82^{18}$ of the Constitution. ${ }^{19}$ [10]

The author took the matter to court. In Lourens 1 [24] the court did not grant the relief sought, but stated:

'In prayer 3 the applicant requests an order which would order Parliament to have all legislation published in all official languages. The order is requested retroactively to 1996 . In terms of section 6(3)(a) of the Constitution, the national government may "use any particular official languages for the purposes of government". Factors which the government should take into account in its decision about which languages to use, are given and then the subsection provides "the national government ... must use at least two official languages". ${ }^{20}$ The applicant contends that Parliament is not part of the national government, and therefore it is not entitled to use only two official languages. According to section 43(a) of the Constitution "the legislative authority ... of the national sphere of government is vested in Parliament". This indicates to me that Parliament is the legislative arm of the national government, but it is

[17 'A Bill assented to and signed by the President becomes an Act of Parliament, must be published promptly, and takes effect when published or on a date determined in terms of the Act.'

[18] 'The signed copy of an Act of Parliament is conclusive evidence of the provisions of that Act and, after publication, must be entrusted to the Constitutional Court for safekeeping.'

[19] 6(3)(a): The national government and provincial governments may use any particular official languages for the purposes of government, taking into account usage, practicality, expense, regional circumstances and the balance of the needs and preferences of the population as a whole or in the province concerned; but the national government and each provincial government must use at least two official languages.' The practice of Parliament in its internal dealings, is to use English, but any member of Parliament may use its own official language in any debate.

[20] Parliament's advocate actually conceded during the trial of Lourens 2 [18] that the first part of section 6(3)(a) of the Constitution cannot apply to the translation obligation in regard to legislative process, but only the second part relating to the prerequisite of two official languages which must be used. not necessary to decide now whether it means that Parliament is part of the...national government. It could be argued that, irrespective of the provisions of section 6(3)(a) of the Constitution, statutes should be available in all eleven of the official languages. For reasons which follow, I also do not need to decide about this now.

'The evidence before the court shows that the Parliamentary rules require that Bills should be prepared in two official languages. One of the Bills must be in English. If Parliament approves the Bill, it is submitted to the President to be assented to and signed. The legislative process is then concluded in terms of section 81 of the Constitution... From both section 81 and 82 it is clear that only one bill, and not multiple translations thereof, is submitted to the President.

'The applicant does not argue that Bills should be translated into all eleven languages. What he requests in prayer 3 is that Parliament should be ordered to have the signed copy of every Act translated into all official languages. I accept in favour of the applicant that statutes should be translated into all the official languages. The question is, however, whether the applicant is correct that Parliament has the duty to do this. I have pointed out that the legislative process is concluded with one copy of the Act. It is that copy which, if the applicant is correct, should be translated into the other 10 official languages. Mr Pelser could not indicate to me a constitutional provision or another rule of law which imposes the translation obligation on Parliament. In fact, in view thereof that the legislative process is concluded when the President assents to and signs the Bill which is submitted, this indicates that Parliament's work has then been finalised and that the obligation to translate the signed Act rests rather on the Executive Authority.'

In Lourens 2 [18] the Equality Court, a division of the High Court, in Cape Town was requested by Lourens to declare the practice of Parliament and/or the Minister of Arts and Culture not to translate and publish all National Legislation in all eleven official languages as unfair language discrimination and to rectify same within a reasonable time.

The Speaker explained the process of a bill after its adoption of Parliament in the Lourens 2 case to be as follows: 'Once Parliament has approved a Bill it is sent to the President for his assent. Once the President has assented thereto, this is announced in the ATC, and the Act is gazetted by the Department concerned or by the Presidency, in both the languages of the official text and the official translation., $^{21}$

'Both versions come back from the Presidency to the Bill's Office, which arranges for same to be sent to the

[21] See section 51 of the first and second respondents' opposing affidavit in $[18]$ 
Constitutional Court for safekeeping. ${ }^{22}$

The court in Lourens 2 [18] stated:

'a second line of attack adopted by the applicant was his contention that parliament's present practice, as encapsulated in joint rules 220, 221 and $222^{23}$, constitutes unfair language discrimination. Parliament's defence to this complaint will be considered in the next section. [26] The discrimination on which the applicant relies is the fact that the 11 official languages are not treated equally ${ }^{24}$ as all National Legislation is not published in all official languages. This argument raises interesting questions as to the meaning of 'official language' and the consequences that flow from such status. It also raises the question as to the meaning of 'discrimination', as defined in s 1(viii) [25], more particularly the question whether the non-publication of National Legislation in all official languages does in fact amount to discrimination.

It is thus Parliament's position that it has only an obligation to publish the legislation in one official language. Their practice to publish it in two official languages, is thus not based on section 81 or 82 , but in terms of their interpretation that parliament is part of National Government as is referred to in section 6(3)(a) of the Constitution. Joint Rules 220, 221 and 222 of parliament were thus drafted in line therewith read together with section 81 and 82. [26]

The question, however, is whether section 6(3)(a) of the Constitution in regard to National Government indeed includes the National Legislature's function to publish legislation.

In terms of section 6(4) of the Constitution, the National Government must regulate and monitor their use of the official languages through legislative and other measures. The Use of Official Languages Act, Act 12 of 2012,25 [27] extended the minimum requirement of official languages to be used by National Government in terms of section 4(2)(c)

[22] See section 52 of the first and second respondents' opposing affidavit in $[18]$

[23] Rule 220: Language requirements for Bills (1) A Bill introduced in either the Assembly or the Council must be in one of the official languages. The Bill in the language in which it is introduced will be the official text for purposes of parliamentary proceedings. (2) The official text of the bill must be translated into at least one of the other official languages and the translation must be received by Parliament at least three days before the formal consideration of the bill by the House in which it was introduced. (3) The cover page of a Bill must specify which language version is - (a) the official text; and (b) an official translation. (4) In parliamentary proceedings only the official text of a bill is considered, but the Secretary must ensure that all amendments to the official text are reflected in the official translation or translations before the official text is sent to the President for assent. Rule 221: Referral of Bills to President for assent: When the official text of the Bill is sent to the President for assent it must be accompanied by the official translation or translations. Rule 222: Subsequent amendments (1) If an Act passed after the adoption of joint rule 220 is amended, the official text of the amendment Bill amending that Act may be in any of the official languages. (2) If the official text of the Bill is not in the same language as the signed text of the Act that is being amended, then one of the official translations of the Bill must be in the language of the signed text.

[24] Applicant never stated in any of the court documents that he requires equal treatment and this was a material oversight of the judge which is part of the pending appeal.

[25] Which commenced on 2 May 2013. to a minimum of three official languages. National Government is defined in the said Act and Parliament is omitted in this definition. 26

It is noteworthy to state that the obligation to regulate and monitor through legislative and other measures are placed on National and Provincial Governments in terms of section 6(4). As section 6(4) is not section '6(3)(c)' of the Constitution, but a separate sub-clause, I suppose it does not warrant the selective interpretation that National Government means only 'National Departments, National Entities and National Public Enterprises', as defined in the Use of Official Languages Act.

In Lourens $2^{27}[18]$ the court found that a possible translation duty of parliament is res judicata in the light of Lourens 1.

Lourens took the matter to the Supreme Court of Appeal ${ }^{28}$ [28]; the Court confirmed that the matter is res judicata ${ }^{29}$ and that the parliament has no duty to translate or publish National Legislation in all 11 official languages. In Lourens 3 the court at least referred to the evidence put by Lourens in Lourens 2 before the Court and criticised parliament of not complying with its own rules but failed surprisingly to find unfair language discrimination. ${ }^{30}$

Lourens contended that the National Assembly failed in its oversight role by failing to scrutinize and to oversee the executive action in this regard. ${ }^{31}$ and this argument was not properly addressed in the Lourens 2 judgment by the court but the Supreme Court of Appeal rejected this argument by stating that it is of no consequence as the Minister of Arts and Culture has no such obligation which should be overseen. ${ }^{32}$ In Lourens 3 the Court, however, stated obiter that Parliament and government should aspire to translate legislation in all Official Languages ${ }^{33}$ and Parliament has failed to comply with its own rules relating to language and has not given effect yet to $\mathrm{s} 4$ of the Use of Official Languages Act. This should be remedied, the court remarked, but the Appeal failed. ${ }^{34}$

\section{The Minister of Arts and Culture's Approach towards the Publication of Legislation in Official Languages}

The Minister of Arts and Culture is the Minister in the executive authority who has been tasked with language issues in South Africa. [29]

[26] The Pan South African Language Board proposed in its proposal the inclusion of Parliament and the decision not to include Parliament, could not have thus been only an omission.

[27] See par 23 and 24 of Lourens 1 [24].

[28] Herein after referred to as Lourens 3.

[29] See par 32 of Lourens 3 [28].

[30] See par 18 and 35 of Lourens 3 [28]

[31] See section 42(3); see also s 55(2)(b) of the Constitution that reads: 'The National Assembly must provide for mechanisms to maintain oversight of (i) the exercise of national executive authority, including the implementation of legislation; and (ii) any organ of state.' [10]

[32] See par 34 of Lourens 3 [28].

[33] See par 32 of Lourens 3 [28].

[34] See par 35 of Lourens 3 [28]. 
Lourens's view is that, in the light of the official status of the 11 official languages, that all National Legislation should be translated and published in all eleven official languages. Lourens alleged that the current practice of Parliament and/or the Minister of Arts and Culture constitutes unfair language discrimination. As an Afrikaans-speaking attorney individualised the consequences of the current practice. $\mathrm{He}$ alleges that the fact that the legislation is not available in Afrikaans, as only a Parliamentary published act can be used officially in courts and in formal publications, unfair language discrimination takes place which prejudices him as individual. ${ }^{35}$ If this practice is rectified, it will also benefit mutatis mutandis the other nine official languages. They will thus all benefit from the outcome of this case.

The Minister's position is that it is the choice of a minister or any individual to choose the language in which the bills are introduced in Parliament. [30] No clear criteria for Ministers are prescribed for the choice of specific languages, of which one is always English, and Lourens replied to this argument that the practice is arbitrarily of nature in so far as its result constitutes unfair language discrimination.

The flaw of this argument, is found in the limitation criteria of the first part of section 6(3)(a). How would usage, practicality, expense, ${ }^{36}$ regional circumstances and the balance of the needs and preferences of the population as a whole or in the province concerned limit the requirement for the translation and publication of the National Legislation in all official languages limit a national right or at the worst, a national expectation of citizens, who are obliged to understand the laws of the land in order to comply therewith. In this regard section 195(1)(d), (e) and (g) of the Constitution are applicable. It provides that public administration must be governed by the democratic values and principles enshrined in the Constitution, including [10]:

(d) Services must be provided impartially, fairly, equitably and without bias; (e) People's needs must be responded to, and the public must be encouraged to participate in policy making; .... and ( $g$ ) Transparency must be fostered by providing the public with timely, accessible and accurate information.'

The core argument of the Minister is, however, that section 6(3)(a) of the Constitution regulates that only two official languages may be used by National Government and the current practice thus does not constitute unfair language discrimination. There is consequently no obligation to translate and to publish National Legislation in more than two official languages.

It is Lourens's view that section 6(3)(a) can only be applicable on the National Government in the day to day administration of the country and the translation duty is not included therein. South Africa has a strong regional

[35] See Harksen [33] regarding the requirement that the complainant must be prejudiced.

[36] In terms of par 99 [31] 703; 2002 (10) BCLR 1075 the Constitutional Court's decision in TAC: 'costs may not be a consideration in the execution of a constitutional obligation'. geographical language demography which requires the different official languages' use in those areas. Furthermore, the minimum requirement prescription of section 6(3)(a) should be read in line with the Sociolinguistic context and that of section 6(2) supra.

If Lourens's interpretation of officiality is upheld, the rule of law requires that the Constitution can only be amended in accordance with the prescriptions of section 74 thereof, and it does not warrant any change to section 6 of the Constitution without the compliance with the peremptory amendment procedure of section 74(3) of the Constitution. His contention is thus also that the practise of the Minister is thus unlawful.

\section{Lourens 2: Equality Court Case}

The Equality Court is a creation of PEPUDA [25], which was promulgated in terms of section 9(2) of the Constitution.

Section 9 of the Constitution is the so-called 'Equality' clause. Language is specifically mentioned in section 1 of PEPUDA as an unfair discrimination ground. It is one of the seventeen specified grounds ${ }^{37}$ of unfair discrimination. The Equality Court is a creature of PEPUDA and the court has wide powers. ${ }^{38}$

The question what constitutes unfair discrimination was described in the President of the Republic of South Africa and Another v Hugo [32]:

'...At the heart of the prohibition of unfair discrimination lies a recognition that the purpose of our new constitutional and democratic order is the establishment of a society in which all human beings will be accorded equal dignity and respect regardless of their membership of particular groups. The achievement of such a society in the context of our deeply in egalitarian past will not be easy, but that is the goal of the Constitution should not be forgotten or overlooked... To determine whether that impact was unfair it is necessary to look not only at the group who has been disadvantaged but at the nature of the power in terms of which the discrimination was effected and, also at the nature of the interests which have been affected by the discrimination. ' par 41 and 43

In Harksen $v$ Lane $N O$ and Others ${ }^{39}$ [33] the considerations and test for the determination of unfairness and the steps which a court must follow are classically set out therein:

'In paragraph $41^{40}$ dignity was referred to as an underlying consideration in the determination of unfairness. The prohibition of unfair discrimination in the Constitution provides a bulwark against invasions which impair human dignity or which affect people

[37] It is not a numeris clausis.

[38] See section 21 of PEPUDA [25].

[39] Paragraph 50-53.

[40] The judge refers to the Hugo case supra. 
adversely in a comparably serious manner. However, as L'Heureux-Dubé $\mathbf{J}$ acknowledged in Egan v Canada, "Dignity [is] a notoriously elusive concept ... it is clear that [it] cannot, by itself, bear the weight of section 15 's task on its shoulders. It needs precision and elaboration." It is made clear in paragraph 43 of Hugo supra that this stage of the enquiry focuses primarily on the experience of the "victim" of discrimination. In the final analysis it is the impact of the discrimination on the complainant that is the determining factor regarding the unfairness of the discrimination.'

The court tabulated the stages of enquiry which become necessary where an attack is made on a provision in reliance on section $8^{41}$ of the interim Constitution. They are [33]:

a) 'Does the provision differentiate between people or categories of people? If so, does the differentiation bear a rational connection to a legitimate government purpose? If it does not, then there is a violation of section 8(1). Even if it does bear a rational connection, it might nevertheless amount to discrimination.

b) Does the differentiation amount to unfair discrimination? This requires a two stage analysis:

i. Firstly, does the differentiation amount to "discrimination"? If it is on a specified ground, then discrimination will have been established. If it is not on a specified ground, then whether or not there is discrimination will depend upon whether, objectively, the ground is based on attributes and characteristics which have the potential to impair the fundamental human dignity of persons as human beings or to affect them adversely in a comparably serious manner.

ii. If the differentiation amounts to "discrimination", does it amount to "unfair discrimination"? If it has been found to have been on a specified ground, then unfairness will be presumed. If on an unspecified ground, unfairness will have to be established by the complainant. The test of unfairness focuses primarily on the impact of the discrimination on the complainant and others in his or her situation. If, at the end of this stage of the enquiry, the differentiation is found not to be unfair, then there will be no violation of section $8(2)$.

c) If the discrimination is found to be unfair then a determination will have to be made as to whether the provision can be justified under the limitations clause. "42 par 52

Sub section 13 (1)(a) of PEPUDA [25] provides that, if the complainant makes out a prima facie case of discrimination,

[41] Section 8 is the equality clause in the Interim Constitution and section 9 is the equality clause of the Constitution of 1996.

[42] See also section 33 of the Interim Constitution and 36 of the Constitution of 1996 . the respondent must prove on the facts before the court that it did not take place as alleged. If the discrimination did take place, section 13(2)(a) provides that if the discrimination on a prohibited ground mentioned in paragraph (a) of the definition of 'prohibited grounds', did take place, then it is unfair, unless the respondent proves that the discrimination is fair. Lourens contended in the Lourens 2 [18] case that a prima facie case was made out and that the burden of proof shifted to the respondents.

In terms of section 14 of PEPUDA [25] the interpretation of fairness is widened and factors to determine fairness or unfairness are set out therein. ${ }^{43}$

The learned author $\mathrm{R}$ Venter analysed Lourens 1 and Lourens 2 and made the following informative remarks [21]:

'Although the court considered the purpose of using only English and one other language during the legislative process, namely so all members can take part in the proceedings, the court did not consider whether that was a legitimate purpose why legislation could not be made available in all the official languages as provided by section 14(3)(f). What would constitute a legitimate purpose for not publishing legislation in all, or at least more of, the official languages and so also refraining from enabling every person in South Africa to read and understand legislation in his or her own language? ... If there is no legitimate purpose to limit the right, other than the rather lame excuse that there is no provision that compels parliament to do so, then the discrimination cannot possibly be fair... Even if parliament's excuse, that there are no provisions which compel parliament to translate legislation, were accepted, the court should still have considered whether there were "less restrictive and less disadvantageous means to achieve the purpose" (s14(3)(h)) ... Furthermore, the factor in section 14(3)(i) also requires the respondent to have taken reasonable steps to either address the disadvantage that was caused or to accommodate diversity. "44 p. 881

The association for lawyers for Afrikaans 45 commissioned a report by $\mathrm{Mr} \mathrm{K}$ Pauw to determine how many amendments and how many new legislated acts are not available in Afrikaans anymore, which was made available to Lourens and which is part of the Lourens 2 [18] record. It patently shows the unfair language discrimination situation.

The finding until March 2014 was as follows:

[43] See par 52 of [33], but it stays relevant notwithstanding the fact that PEPUDA was promulgated after the Harksen case. See also S14(2)(b) read with S14(3) of PEPUDA [25].

[44] S14(3) of PEPUDA [25]: '(f) whether the discrimination has a legitimate purpose; (h) whether there are less restrictive and less disadvantageous means to achieve the purpose; (i) whether and to what extent the respondent has taken such steps as being reasonable in the circumstances to - (i) address the disadvantage which arises from or is related to one or more of the prohibited grounds; or (ii) accommodate diversity.'

[45] The 'Vereniging van Regslui vir Afrikaans': founded on 8 June 2002 in order mainly to promote Afrikaans as legal language. 
There are 144 principal Acts, which are not published in Afrikaans, since 1994.

There are 65 principal Acts, which were published initially also in Afrikaans, which were amended in English and another official language since 1994 and consequently they are not in their entirety available in Afrikaans anymore as they have not been published in or officially translated into Afrikaans. ${ }^{46}$

There are 205 Acts that are not translated into Afrikaans, or that have provisions that have not been translated into Afrikaans, or have provisions that have been negatively influenced by other Acts of which the provisions have not been translated into Afrikaans.

It must be emphasised that no such report is available for the nine African languages. Parliament provided a list of acts from 2009 to 2013 in which languages Acts where published: According to the said evidence, the haphazard and arbitrarily choice by Ministers of the second language in which the legislation should be published, causes that no coherent corpus of legislation in the African languages exist. According to the current practice only a very limited part of South Africa's National Legislation is thus available at any stage in any of the African languages.

In the light of the intricate cross referencing and amendment structure of legislation, the current practice of publication in African languages of legislation, boils down to tokenism as it has no real practical value. The need for it is according to the elite view, non-existent. The Black Lawyers Association's position is that they do not require the legislation in the indigenous languages as they use English. [34]

In the light of the fact that the state may not discriminate unfairly also on language grounds, the factual position is that English is the only language in which all Acts are published. There is thus only a total corpus of English legislation available.

On 17 September 2014 the court found in favour of the respondents and dismissed Lourens's action against respondents. He found that:

'There is no constitutional or statutory duty on any of the respondents to publish all National Legislation in all official languages, nor to translate all National Legislation into all official languages. Where such a duty is imposed, it is done so expressly, e.g. in s31(2)(b) of the Equality act.

'To the extent that publication of legislation in only two official languages may be discriminatory, such discrimination is fair as contemplated by s 13(2)(b)(ii) of the Equality Act. To the extent that the Joint Rules of Parliament, permitting the use of only two official languages, may be discriminatory, such discrimination

[46] This is directly in contravention with Joint Rule 222 [26] which requires that amendments should be done in the original principal Act's language and at least on this issue, Lourens should have been successful in the Lourens 2 [18] case, as it clearly constitutes unfair language discrimination. is fair as contemplated by s 13(2)(b)(ii) of the Equality Act.' par 32 [18]

An application for leave to appeal was successful and the appeal was heard and the judgment on appeal was delivered on 10 March 2016.

\section{Lourens 3: Supreme Court of Appeal}

The Supreme Court of Appeal dismissed the appeal as it found, as stated in paragraphs 5.10 and 5.11 supra, that the case against Parliament is res judicata and the Minister does not have the obligation to translate all National Legislation in all 11 Official Languages. The Court also accepted Parliament's standpoint that it is a legitimate excuse not to publish all the National Legislation in all official languages due to the constraints of resources and time limitations, ${ }^{47}$ notwithstanding an admission that it is indeed possible over time. Consequently, the practice as proven by the evidence did not constitute unfair language discrimination according to the Court.

The positive finding, although it is only obiter, is that there is an obligation on the National Government to translate National Legislation in terms of the Use of Official Languages Act, in at least three official languages. Furthermore, that Parliament has to rectify the transgressions of its own rules in the light of the evidence mentioned in 7.5.2 supra.

An application for leave to appeal to the Constitutional Court was filed on 6 April 2016 and the Constitutional Court refused leave to appeal as it states that there as it lacks prospects of success, on 14 July 2016. The referral of the matter to the African Court on Human and Peoples' Rights or to the United Nations Human Rights Council is currently under consideration.

\section{Some Reflections on a Correct Judicial and Practical Approach}

The South African courts should and do not interfere normally with the executive and legislative sphere of Government in the light of the South African version of the doctrine of separation of powers. ${ }^{48}$ In Van Rooyen $v S$ [35] the constitutional court aptly summarised this approach as follows:

In a constitutional democracy such as ours, in which the Constitution is the supreme law of the Republic, substantial power has been given to the judiciary to uphold the Constitution. In exercising such powers, obedience to the doctrine of the separation of powers

[47] See par 21 of Lourens 3 [28].

[48] The legislative and executive spheres of government are 'married' in the sense that the governing party also chooses the president and he/she chooses the cabinet who are the main role players in parliament in regard to the introduction of legislation. 
requires that the judiciary, in its comments about the other arms of the state, show respect and courtesy, in the same way that these other arms are obliged to show respect for and courtesy to the judiciary and one another.' par 34

The learned author $\mathrm{R}$ Venter gave the following insightful comments in regard to the Lourens 1 and Lourens 2 decisions: [21]

If it has been found, as was found in these cases, that an obligation to translate legislation exists, but there are no legislative provisions or other rules that determine exactly which organ has this obligation, then there is lacuna with regard to this particular issue and the obligations vests in the national government as a whole. Consequently parliament, as the legislative branch of government, could have been ordered to create a rule to give effect to the translation of national legislation (rule 2(1) of the rules of the national assembly give the speaker the authority to make a ruling or frame a rule to make provisions for instances for which the rules do not provide) or the minister of arts and culture, as part of the national executive authority, could have been ordered to initiate legislation to regulate the translation of legislation. ' $\mathrm{p}$. 882

In the light of the separation of powers doctrine as aforesaid, the outcome of the case should be, in my view, the finding that Parliament and the Minister of Arts and Culture discriminates unfairly on the basis of language and that they are given a specified time period, with regular reports to the court that they are complying, within a specified time period to rectify the discriminatory practice.

You may ask: was there any request from Parliament or the National Executive to resolve this dispute? No, never! The matter should have been resolved with a practical approach with a proper language implementation plan.

Practical suggestions to reach the target of officiality of all eleven official languages, which will always be a relative situation given the historic developments of the languages, are for instance: (The fact that the demand is that all the South African National Legislation should be translated which may be a massive task, is a veiled attack as the part of the legislation of the pre 1994 period was already substituted, amended or repealed.)

All general laws should thus be prioritised;

Core legislation should be first identified and translated and published formally by Parliament in order to grant it formal status;

Certain unused legislation can be identified even not to be translated, unless a language group requests the translation which will then be done on demand;

The expert, Mr K Pauw, counted the average words of a year's legislation and in the light of a normal translators' ability to translate 2000 words per day, two translators per language would be needed to translate the legislation annually and at least two translators should thus be appointed per language; ${ }^{49}$

Other practical steps could have been outsourced to subsidised accredited language agencies to translate relevant legislation for the specific language groups. The publication of the legislation then should be granted formal status through authorising legislative measures;

A proper training plan together with the universities' co-operation should be developed;

The standardisation of the four Nguni official languages and the three Sotho official languages as a cost saving measure can be considered;

The addressing of the latent language question, which is caused by the migration of people from the other Southern African countries, which requires an integrated Southern African approach towards language development;

The aforesaid measures should form part of the National Language plan.

The following hermeneutic approach should be adopted by a judge and I quote from the former Constitutional Court's Judge Laurie Ackermann [37] where he authoritatively lays down the approach which the Judges should have followed in the interpretation of the word 'officiality':

'It is for the court, and ultimately the Constitutional Court, to say what the provision of the Constitution mean. At best the interpreter can remain aware at all times of her own history of ideas when seeking to apply "objectively" the conventional interpretative tools. One of the most important of these tools is of course the purpose of the particular constitutional provision, determined in the context of the Constitution as a whole and its overall purpose. It should be self-evident that in order to determine this purpose, history cannot be excluded. On the contrary, without considering history it would be impossible to ascertain this purpose with any pretence of objectivity or certainty.' p. 26

Judge Ackermann continues: [37]

'...Yet the Constitution is not a detailed and comprehensive code, spelling out elaborately and minutely the full content of these rights and values. The Constitution does not itself interpret these rights and values. This is left to the judicial interpreter. The interpreter is not the Constitution speaking, but human being seeking to give meaning to a non-comprehensive text. Part of this task is to determine the purpose of the text. Aspects of this purpose emerge (though never fully) from the text itself and from the historical setting preceding the particular text in question ...' page 28

It is my humble contention that the deep flaw in the Lourens 2 and 3 judgments, which actually de facto declares the 'official status' of the eleven official languages as

[49] The annual remuneration of a level eight (8) translator ranges between R91404 to R107670 and that of a level nine (9) between R311748 to $\mathrm{R} 376626(1 \$=\mathrm{R} 15.00)$ see $[36]$ 
symbolic official languages, is the failure of the judges to interpret officiality within the Supreme Law of the land in accordance with the aforesaid hermeneutic approach. Thus the restoration of human worth (dignity) as a basis of section 9 of the Constitution, is infringed by the Lourens 2 and 3 judgments and perpetuates the current unfair language discrimination regarding the translation and publication of National Legislation. The judgments in Lourens 2 and 3 were thus a temporary setback, but will hopefully be rectified on appeal.

In the light of the Lourens 2 and 3 judgments, as the Lourens 1 judgment left the answer to the problem open as Judge B du Plessis concurred that National Legislation should be published in all official languages, the only conclusion at this stage can only be that the 'unofficial' text of government's section 6 of the Constitution of the RSA reads as follows: [10]

\section{'6.1 The official language of South Africa is English.}

'6.1.1 The following languages are recognised as more important than these mentioned in sub section '6(5)(b) Sepedi, Sesotho, Setswana, SiSwati, Tshivenda, Xitsonga, Afrikaans, isiNdebele, isiXhosa and isiZulu.

'6(2) Recognising the historically diminished use and status of the indigenous languages of our people, the state must take practical and positive measures to elevate the status and advance the use of these languages.

'6(3) ...The national government, the provincial governments and municipalities may use any particular official languages, in addition to English.

'6(4) the National government, which excludes parliament, and provincial governments, by legislative and other measures must regulate and monitor their use of official languages.

'6(5) The Pan South African Language Board is dissolved and is substituted by the National Language Unit under the control of the Language-General, which is created herewith, in the office of the President which will execute the functions of the abolished PanSalb and that of the National Language unit in the department of Arts and Culture. ${ }^{50}$

\section{Intellectualisation through Translation}

The translation of the National Legislation into the official languages, with specific reference to the African languages, would have enhanced them in their intellectualisation (modernising) process and the purpose of section 6(2) would have been achieved. A specific obligation was placed in terms of Sub section 6(2) on the state to take practical and positive measures to elevate the status and advance the use of the indigenous languages based on the declared recognition of the historically diminished use and status of the

[50] This is my submission in regard to s6(5) as the Pan South African Language Board has been dysfunctional for many years. indigenous languages of the people of South Africa.

Rosalie Finlayson and Mbulungeni Madiba [38] evaluated the position regarding the state of intellectualisation of the nine African languages as follows:

'Although all nine indigenous languages have been partially developed, that is, they have written forms, literary works, dictionaries and terminology lists, they are lagging far behind in the area of modern terminology as compared to the neo-colonial languages. ... Despite many problems, with a clear national language policy and plan, intellectualisation in South Africa is more likely to succeed than in most developing countries. Research that is being conducted on strategies towards language intellectualisation provides a strong sense of optimism that this process of language intellectualisation will achieve increasing degrees of momentum, support and success.' p. 40

In regard to the intellectualisation obligation of the African languages, Dr Neville Alexander ${ }^{51}$ [2] emphasised the role of Pan South African Language Board and its substructures, the Provincial Language committees, the National Language bodies, lexicographic units, as well as the National Language Service of the Department of Arts and Culture, which have a very important role to play in conjunction with departments of African languages at universities ${ }^{52}$ to make sure that these languages are developed, elaborated and used in all possible functions. He proceeds to say that it is, moreover, their duty to mediate with government, to make a noise, to put pressure on government, to see to it that a budgetary allocation should be increased radically for language planning and language development in South Africa. The proclamation of the 'African Renaissance' by former President T Mbeki a new opportunity has been created for concrete economic, political and socio-cultural reasons, the language question has to be, and in fact is being, reviewed by most of the leadership of the African continent. The most urgent and decisive reason for this review is the palpable failure of education in Africa. Dr Neville Alexander ${ }^{53}$ [2] referred to Bamgbose: '... unless the educational systems of the continent are based on the mother tongues of the people of Africa instead of on foreign languages as most of them are at present, all attempts at establishing a platform for improving them are at present, all attempts at establishing a platform for improving the quality of education will in the final analysis benefit only the elite and its progeny... ${ }^{54}$ [40-41]. The current problems with the South African educational system are scientific proof of this contention.

The enforcement through the court of this obligation on the basis that the failure constitutes unfair language

[51] Page 280.

[52] See also [39].

[53] Page 308.

[54] The most recent evidence as to whether the population of South Africa can understand English is set out in the Department of Basic Education, South Africa Report on the national senior certificate examination 2011 national diagnostic report on learner performance. 
discrimination, is in my view very unfortunate as the Government should have complied out of its own with the Constitutional obligation and with its commitment with the African Union ${ }^{55}$.

The failure to translate the National Legislation in all official languages is not only a failure to comply with this constitutional obligation, but also a total failure on the Government's part to intellectualise the African languages through translation.

A constitutional sanctioned project to translate and publish the legislation in all official languages, would have caused the advancement of the development of digital translation which is my opinion the main feature for the sustainable development of all smaller languages. ${ }^{56}$

\section{Conclusions}

The capitulation towards an English hegemony only, is not in my vocabulary, and whether I and those who are of the same opinion is right or wrong, is the privilege not of my contemporaries, but that of future generation's historians. The so called realists with their 'know it alls' with their colonized minds, argument that it is impracticable and even insane, will be opposed and will in my view, be proved to be wrong.

The road ahead may be long and exhaustive, but the cause is worthwhile to strive for the preservation of diversity and the recognition of the human worth of the many previously colonised people. Let us persuade the doubters with firm and resolute actions.

The declaration of the Nine African languages as 'official' languages, is a road towards, and not a destination and will require real commitment to reach the target of real officiality. An assimilationist or homogenisation policy of the current government, to use only English militates thus directly against the embedded value of human worth and obviously undermines multilingualism and the motto of the country.

\section{Bibliography}

Kevin Mgwanga Gunme et al. v. Cameroon, African Commission on Human and Peoples' Rights, Communication 266/2003, 27 May 2009, par. 102, 129, Available online from

http://caselaw.ihrda.org/doc/266.03/view/. [Accessed on 2 June 2016].

\section{Brief Biography}

1. Cornelius JA Lourens is a practising attorney in South Africa with twenty-six years' experience as trial

[55] African Academy of Languages (ACALAN) established on 19 December 2000; see [2] page 309.

[56] The human oversight can never be excluded. lawyer with a right of appearance in the lower and higher courts.

2. A founder member of the Association of Lawyers for Afrikaans (Vereniging van Regslui vir Afrikaans)

3. A Language rights activist who successfully:

3.1. Forced the South African National Government to enact language legislation in the case Lourens v The President of the Republic of South Africa \& others [2010] JOL 25222 (GNP). (http://www.saflii.co.za)

3.2. Forced the Minister of Justice and Constitutional development to comply with section 21(2)(b) of the Promotion of Equality and Prevention of Unfair, Discrimination Act, Act 4 of 2000 to publish the said Act, regulations and forms in all eleven official languages in the case CJA Lourens v Minister of Justice and Constitutional Development, case number: 33653/2011.

4. Various other cases against the provinces to enact Provincial Language Legislation.

5. Applicant in the case Lourens $\mathrm{V}$ Speaker of the National Assembly and others [2014] JOL 32641 (EqC) regarding the publication of all National Legislation in all official languages.

6. Married to Sarita Lourens with one son, Christiaan Lourens.

7. See website: www.lourensprokureurs.com for full particulars.

\section{REFERENCES}

[1] Certification of the Constitution of the Republic of South Africa, 1996 (CCT 23/96) [1996] ZACC 26; 1996 (4) SA 744 (CC); 1996 (10) BCLR 1253(CC).

[2] L Busch, B Busch, K Press (editors). Interview with Neville Alexander: The Power of Languages against the Language of Power, University of KwaZulu-Natal Press, 102, 139, 154, 280, 308, 1978 .

[3] Mandela N Sunday Times, 25 April 2004.

[4] M Wilson, LL Thompson (editors), Oxford History of South Africa, 73-74, 1978.

[5] Union of South Africa. Official Languages of the Union Act, Act 8 of 1925 .

[6] Republic of South Africa. Republic of South Africa Constitution, Act 32 of 1961.

[7] Republic of South Africa. Republic of South Africa Constitution, Act 110 of 1983.

[8] WL Seriti. Can a Provincial Legislature use only one of the Official Languages, De Rebus, 47, November 1994.

[9] Republic of South Africa. Constitution of the Republic of South Africa, Act 200 of 1993.

[10] Republic of South Africa. Constitution of the Republic of 
South Africa, Act 108 of 1996.

[11] Ex Parte Chairperson of the Constitutional Assembly: in re Certification of the Constitution of the Republic of South Africa 1996 (4) SA 744(CC).

[12] J.G.A Diergaart (late Captain of the Rehoboth Baster Community) et al. v. Namibia. Communication No. 760/1997, UN Doc. CCPR/C/69/D/760/1997 (2000).

[13] F de Varennes. Discussion report: International and comparative perspectives in the use of official languages models and approaches for South Africa, 31-35, 2012, Online available at http://www.academia.edu/2361055/International_and_Comp arative_Perspectives_in_the_Use_of

Official_Languages_Models_and_Approaches_for_South_A frica. [Accessed: 2 June 2016].

[14] Mentzen alias Mencina v Latvia Application no 71074/01, admissibility decision of 7 December 2004, Online available from http: //bit.ly/1pxGhTR. [Accessed on 2 June 2016].

[15] Republic of Latvia. Constitution of Latvia, 1922.

[16] Republic of Latvia. Latvian Official Languages Act, 2007.

[17] African Commission on Human and People's Rights, Communication 266/2003, 27 May 2009.

[18] Lourens $v$ Speaker of the National Assembly and others [2014] JOL 32641 (EqC).

[19] Re Manitoba Language Rights [1985] 1 S.C.R. 721.

[20] ED Faingold. Language rights and language justice in the constitutions of the world, Language Problems \& Language Planning, Vol. 28, No. 1, 11-24, 2004.

Egan v Canada [1995] 2 S.C.R.

[21] R Venter. Are some official languages more equal than others? Reflections on Constitutional duties toward official languages, the Use of Official Languages Act and respecting diversity, TSAR, 4, 872-886, 2015.

[22] Constitution of Singapore Bill No. B 43 of 1965.

[23] The Constitution of the Democratic Republic of the Congo, 2005.

[24] Lourens $v$ The President of the Republic of South Africa \& others [2010] JOL 25222 (GNP), Online available at http://www.saflii.co.za._[Accessed on 2 June 2016].

[25] Republic of South Africa. Promotion of Equality and Prevention of Unfair Discrimination Act, Act 4 of 2000 (also known as PEPUDA/Equality Act).

[26] South African Government. Rules of Parliament. 2016. Available from http://www.gov.za/about-government/rules-parliament. [Accessed on 2 June 2016].

[27] Republic of South Africa. Use of Official Languages Act, Act 12 of 2012.

[28] Lourens $v$ Speaker of the National Assembly of Parliament and Others (20827/2014) [2016] ZASCA 11; [2016] 2 All SA 340 (SCA).

[29] Department of National Treasury. National budget 2008. [updated 2016], Online available from http://www.treasury.gov.za/documents/national\%20budget/2 008/ene/12\%20arts.pdf. [Accessed on 2 June 2016].

[30] Oriani-Ambrosini, MP Speaker of the National Assembly (CCT 16/12) [2012] ZACC 27; 2012 (6) SA 588; 2013 (1) BCLR 14 (CC).

[31] Minister of Health and Others $v$ Treatment Action Campaign and Others (No 1) (CCT9/02) [2002] ZACC 16; 2002 (5) SA 703; 2002 (10) BCLR 1075 (5 July 2002).

[32] President of the Republic of South Africa and Another v Hugo 1997 (6) BCLR 708 (CC).

[33] Harksen $v$ Lane NO and Others 1997 (11) BCLR 1489 (CC).

[34] Rapport newspaper, 3 November 2002.

[35] Van Rooyen v S 2002 (5) SA 246 (CC).

[36] Republic of South Africa. National Assembly Internal Question Paper, Question no. 1455 (1(c)(i)), dated 13 May 2016.

[37] L Ackermann. Human Dignity: Lodestar for Equality in South Africa, Juta \& Co., Cape Town, 2012.

[38] R Finlayson \& M Madiba The intellectualisation of the Indigenous Languages of South Africa: Challenges and Prospects, Current Issues in Language Planning, Vol. 3. No.1, 40-61, 2002.

[39] Ministry of Education. Ministerial Committee. The Development of indigenous African languages as mediums of instruction in higher education, September 2003.

[40] A Bamgbose. Language and exclusion: The consequences of language policies in Africa. Hamburg, 76-77, 2000.

[41] P Obanya. Revitalizing Education in Africa, 192-203, 2000. 